\title{
The exhumation of the Indo-Burman Ranges, Myanmar
}

3

4

5

6

7

8

9
Yani Najman ${ }^{a *}$, Edward R. Sobel ${ }^{b}$, Ian Millarc, Daniel F. Stocklid, Gwladys Govin $^{\text {at }}$, Frank Lisker ${ }^{\mathrm{e}}$, Eduardo Garzanti ${ }^{f}$, Mara Limonta $^{f}$, Giovanni Vezzoli ${ }^{f}$, Alex Copley $^{g}$, Peng Zhang ${ }^{\text {, }}$ Eugene Szymanski', Alicia Kahn'.

aLEC, Lancaster University, Lancaster, LA1 4YQ, UK.

b Institut für Geowissenschaften, Universität Potsdam, Karl-Liebknecht-Strasse 24-25, 14476, Potsdam-Golm, Germany

c BGS Keyworth, Nottingham, NG12 5GG, United Kingdom

${ }^{d}$ The University of Texas at Austin, Department of Geological Sciences, Jackson School of Geosciences, 1 University Station C1100, Austin, TX 78712, USA

e Fachbereich Geowissenschaften der Universitat Bremen, Postfach 33028334 Bremen, Germany.

${ }^{f}$ Laboratory for Provenance Studies, Department of Earth and Environmental Sciences, University of Milano-Bicocca, 20126 Milano, Italy

gDepartment of Earth Sciences, Bullard Labs, Cambridge University, Cambridge CB2 3EQ, UK

$\mathrm{h}$ Key Laboratory of Tectonics and Petroleum Resources (China University of Geosciences), Ministry of Education, Wuhan 430074, China

i Earth Science Department, Chevron Energy Technology Company, Houston, TX 77002, USA

* corresponding author. Email: y.najman@lancs.ac.uk

+ deceased. 
The Indo-Burman Ranges (IBR) are a mountain range comprised of Mesozoic-Cenozoic rocks which run the length of Western Myanmar, extending into India and Bangladesh; to the west lies the Indian Ocean, and to the east lies the Central Myanmar Basin (CMB) along which the Irrawaddy River flows. The IBR are considered to be an accretionary prism, developed at the juncture of the Indian and Sunda plates, and a number of hypotheses have been proposed for their evolution. However, in order for these hypotheses to be evaluated, the timing of IBR evolution needs to be determined. We undertook a two-pronged approach to determining the timing of uplift of the IBR. (1) We present the first lowtemperature thermochronological age elevation profile of the IBR using ZFT, AFT and ZHe techniques.

Our data show: a major period of exhumation occurred around the time of the Oligo-Miocene boundary; we tentatively suggest, subject to further verification, an additional period of exhumation at or before the late Eocene. (2) We carried out a detailed multi-technique provenance study of the sedimentary rocks of the IBR and Arakan Coastal region to their west, and compared data to coeval rocks of the $\mathrm{CMB}$. We determined that during Eocene times, rocks of the $\mathrm{CMB}$ and IBR were derived from similar local provenance, that of the Myanmar arc to the east. Therefore at this time there was an open connection from arc to ocean. By contrast, by Miocene times, provenance diverged. Rocks of the $\mathrm{CMB}$ were deposited by a through-flowing Irrawaddy River, with detritus derived from its upland source region of the Mogok Metamorphic Belt and Cretaceous-Paleogene granites to the north. Such a provenance is not recorded in coeval rocks of the IBR, indicating that the IBR had uplifted by this time, providing a barrier to transport of material to the west. To the previously published list of viable proposals to explain the exhumation of the range, we add a new suggestion: the period of exhumation around the time of the Oligo-Miocene boundary could have been governed by a change to wedge dynamics instigated by a major increase in the thickness of the incoming Bengal Fan sediment pile. 
49 Keywords: Indo-Burman Ranges, age-elevation profile, provenance, Myanmar, detrital 50 thermochronology and geochronology, palaeo-Irrawaddy.

51 Highlights:

52 - $1^{\text {st }}$ low temperature thermochronological age-elevation profiles of the IBR, Myanmar

- Major exhumation around the Oligo-Miocene boundary; possible earlier event by latest

54 Eocene

55 - Divergence of provenance east and west of IBR by Miocene, consistent with timing of uplift 
The Indo-Burman Ranges (IBR) are a Cenozoic mountain belt running the length of Western Myanmar, extending into India and Bangladesh (Fig 1A). They lie on the Burma Platelet, located between the Asian Sunda Plate to its east and the Indian Plate to its west. The tectonics of the region are dominated by the oblique collision of India subducting north-east beneath Asia. The Burma Platelet is comprised of the IBR in the west, and the Central Myanmar Basin (CMB) in the east, separated from the IBR by the Kabaw Fault (Mitchell, 1993). Today, the Irrawaddy River flows southwards along the CMB, but prior to uplift of the IBR, the region would have been open to the ocean to the west.

The CMB, split by the Wuntho-Popa Arc, consists of the Western (forearc), and Eastern (backarc) subbasins filled with Cenozoic sediment. The IBR is a west-vergent accretionary wedge building at the subduction trench of the down-going Indian oceanic plate (e.g. Curray, 2014), part of a subduction system that may have been ongoing since the Jurassic (e.g. Zhang et al., 2018 and references therein). The mountain range is comprised of westward-younging Mesozoic-Cenozoic sedimentary rocks, with a metamorphic core to the east (Socquet et al., 2002).

The oblique nature of the India-Sunda convergence has resulted in partitioning of the CMB into a series of en-echelon trans-tensional pull-apart basins. The importance of the obliquity of collision on the IBR's exhumation is debated, with numerous other mechanisms also proposed for IBR evolution (Acharyya, 2015; Bertrand and Rangin, 2003; Licht et al., 2018; Maurin and Rangin, 2009a; Rangin et al., 2013).

Understanding the tectonic evolution of the IBR requires knowledge regarding when it formed. The development of the younger western side of the fold-thrust belt has been dated at $\sim 2 \mathrm{Ma}$ (Maurin and Rangin, 2009b; Najman et al., 2012) and continues to present day. However, the onset of the IBR's exhumation, at its oldest, eastern, extent is not well known; submarine formation of the accretionary 
elevations some time between the late Eocene to mid Miocene (Licht et al., 2018; Licht et al., 2014;

We analysed samples from the IBR (Fig. 1B, Fig 2A, SI 1) to document the exhumation history of the orogen using two approaches: we provide the first age elevation profiles for the IBR from zircon and apatite fission track (ZFT, AFT) and zircon helium (ZHe) data. We couple this with a provenance assessment of Cenozoic rocks from regions east and west of the IBR using detrital zircon and rutile U$\mathrm{Pb}$ data, zircon $\mathrm{Hf}$ isotopic characterisation, zircon fission track ages, bulk rock $\mathrm{Sr}-\mathrm{Nd}$, and petrography and heavy mineral analysis. The rationale behind the provenance approach is that provenance signatures should be similar in locations both east and west of the IBR when the region of the CMB was open to the ocean to the west, but should diverge after uplift of the IBR barrier.

\section{Background geology}

\subsection{The Central Basin (CMB)}

The $\mathrm{CMB}$, through which the Irrawaddy River flows, consists of Paleogene marine to Oligo-Miocene continental facies (Licht et al., 2013). The basin is divided by the Wuntho-Mt Popa Arc (Mitchell et al., 2012) into a western forearc basin, and eastern backarc basin. To its north, from which the Irrawaddy headwaters flow, lies the Mogok Metamorphic Belt (MMB), which consists of low to high grade metamorphic rocks, metamorphosed and exhumed during the Eocene to early Miocene (e.g. Barley et al., 2003), and Cretaceous-Paleogene granitoids (e.g. the Dianxi-Burma Batholiths of the MMB and the Bomi-Chayu Batholiths of the Eastern Transhimalaya (Liang et al., 2008)). The MMB Eocene rocks of the $\mathrm{CMB}$ show a strong arc-derived provenance signature, interpreted as derived from the proximal Wuntho-Popa Arc (Licht et al., 2013; Licht et al., 2014; Oo et al., 2015; Wang et al., 2014; Zhang et al., 2019). First appearance in the CMB of detritus derived from the Mogok Metamorphic Belt and spatially associated granites occurred sometime between the late Eocene to mid Oligocene (Licht et al., 2018; Zhang et al., 2019). This, along with major influx of such material in the latest Oligocene, is interpreted 
as indicative of input from the Irrawaddy headwaters, and thus progressive emergence of the Irrawaddy River as a major through-going river (Zhang et al., 2019). This interpretation is consistent with that of Licht et al. (2014), who propose that the stable provenance signature from the Neogene indicates establishment of a long-standing stable trunk river.

\subsection{The IBR and western coastal region}

The IBR lie west of the Kabaw Fault (Fig. 1). Maurin and Rangin (2009b) divide the IBR into an Eastern "IBR core", an "Inner IBR" to the west, and furthest west the "Outer" IBR. The Inner and Outer IBR are separated by the Kaladan Fault, along which the degree of dextral strike-slip motion is debated (e.g. Betka et al., 2018). The Inner IBR is separated from the IBR core to its east by the Lelon (Churachandpur-Mao) dextral transpressional west-verging shear zone (Fig. 1B).

\subsubsection{Age constraints of the IBR rocks.}

The most detailed country-wide geological map (Burma Earth Sciences Research Division, 1977) depicts the eastern IBR core, in the Mt Victoria region (Fig 2A), as consisting of Jurassic ophiolites (Suzuki et al., 2004), Cretaceous and Triassic turbidites (Sevastjanova et al., 2015), and Kanpetlet Schist "basement". The Inner IBR consists of Eocene sedimentary rocks, and the Outer IBR consists of Miocene, and furthest west, Mio-Pliocene sedimentary rocks. Facies are largely turbiditic, until late Miocene when shallow marine and/or fluvial sediments were deposited (Naing et al., 2014). We use the age assignments of the map of the Burma Earth Sciences Research Division (1977), updating the ages with more recent data, where appropriate, as described below.

The Triassic schists of the IBR Core: In the IBR Core, the age of the schists has been considered preMesozoic (Brunnschweiler, 1966) or Triassic (Socquet et al., 2002). Recent detrital zircon age data (Zhang et al., 2017a; this study, sample MY16-14A; Fig 3) indicates a Triassic or younger age. 
see section 4.2.1), contains Paleogene detrital zircons, with the youngest population indicating reassignment to a Lutetian, (or younger) depositional age. Bender (1983) noted the allochthonous nature of some of the Cretaceous outcrops, and reworking of some Cretaceous fossils in Cenozoic units. This, or unmapped structural interleaving of Eocene and Cretaceous rocks, may be the cause of the mismatched age assignments. Based on one sample alone, it is not possible to speculate as to the spatial extent to which this unit's age may need to be reassessed.

The Eocene sedimentary rocks of the Inner IBR: the majority of the rocks were once considered to be no younger than early Eocene (Mitchell, 1993). However maximum depositional ages determined from detrital zircon $\mathrm{U}-\mathrm{Pb}$ and fission track ages show that the age extends into the mid Eocene (Allen et al., 2008; Naing et al., 2014; this study, sample MY16-60A, see section 4.2.1).

Neogene rocks of the Outer IBR: The geological map of the Burma Earth Sciences Research Division (1977) maps the coastal Arakan rocks of the Outer IBR as Miocene, and furthest West as Mio-Pliocene. Some rocks assigned to the Miocene on this map are debatably assigned to the Eocene or Oligocene on other maps (e.g. Myanmar Geosciences Society 2017). Rocks mapped as Neogene are consistent with ZFT data (Allen et al., 2008) and our new biostratigraphic data which indicate that rocks span early, mid and late Miocene times (SI 2); such data, where available, are more consistent with the map of the Burma Earth Sciences Research Division (1977) than some later maps.

\subsubsection{Tectonic evolution of the IBR}

The tectonic evolution of the IBR is poorly constrained. Mitchell et al. (2010) and Zhang et al. (2017a) favour initial formation of the IBR accretionary prism since the Cretaceous, based on unconformities of this age in the $\mathrm{CMB}$, and dating of a sub-ophiolitic metamorphic sole, respectively (see also Liu et al., 2016). 
Licht et al. (2013) argue for IBR uplift sometime between the mid Miocene, when deltaic CMB facies prograded south, and mid Eocene, when $\mathrm{CMB}$ deltas prograded westward, indicating at that time no uplifted IBR land barrier and the region open to the Indian ocean to the west. This is consistent with data from Eocene turbidites of the IBR which have a similar petrographic and isotopic signature to Eocene rocks of the $\mathrm{CMB}$ and the same interpreted local eastern Myanmar-arc provenance (Allen et al., 2008; Naing et al., 2014). Licht et al. (2014) proposed limited uplift of the IBR in the Oligocene based on a slightly more mafic Sm-Nd signature of Oligocene CMB rocks compared to units above and below. Those authors considered that uplift could not be substantial, given the low sediment accumulation rates in the $\mathrm{CMB}$ at the time. By Miocene times, a homogeneity of $\mathrm{CMB}$ provenance data, interpreted to indicate a stable Irrawaddy trunk river,, requires an uplifted IBR to channel the river on its western flank. A later study interpreted upper Eocene rocks of the CMB to be barrierbound estuarine facies, with the barrier taken to be the rising IBR (Licht et al., 2018).

Ridd and Racey (2015a) surmise that a lack of westward thinning CMB Paleogene strata indicate open ocean rather than an IBR-bounded basin margin lay to the west. However, they considered that prior to the late Miocene, the IBR region may have been at least partly a land area (Ridd and Racey, 2015b).

\section{Approach and methods}

In order to determine the timing of exhumation and uplift of the IBR, we use two approaches:

1) Construction of an east-west transect across the IBR, using ZFT, AFT and ZHe techniques, based on the assumption that the time of cooling is linked to exhumation driven by rock uplift.

2) A provenance study of the IBR and a comparison of such data with equivalent data from the CMB. IBR uplift would act as a barrier across which material from the $\mathrm{CMB}$ could not pass westward to the ocean. Thus, prior to uplift, when the region of the CMB was open to the ocean, both the CMB and IBR should display similar provenance, previously interpreted as derived from the Wuntho-Popa Arc to the east (sections 2.1 and 2.2.2). The uplifting IBR 
formed the margin to the river basin along which the emergent Irrawaddy River flowed, and acted as a barrier such that material from the Mogok Metamorphic Belt and granite headwaters of the Irrawaddy was unable to be transported to the Arakan coast. Therefore the time of divergence of provenance should reflect the timing of IBR uplift .

Analytical methods are summarised below, and provided in full in SI 3 for every method.

\subsection{Age elevation profiles}

Samples for age elevation profiles were collected across an east-west transect which has $\sim 2400 \mathrm{~m}$ of relief over $\sim 60 \mathrm{~km}$ and crosses two prominent shear zones (the Lelon and Kabaw Faults; see section 2.2 and Fig. 2). Therefore, the transect is interpreted as three discrete profiles.

\subsubsection{Zircon fission track (ZFT) analysis}

Ten ZFT samples were prepared at Universität Potsdam and analysed at Universität Bremen by the external detector method.

\subsubsection{Zircon (U-Th)/He dating method (ZHe)}

Nine samples with two to six single grains were analysed, spanning the available stratigraphic and topographic range. These data shows whether samples experienced temperatures of $\sim 180^{\circ} \mathrm{C}$ (e.g. Reiners and Brandon, 2006) during the Cenozoic.

\subsubsection{Apatite fission track method (AFT)}

Eleven samples were analyzed for age determinations.All of the analyzed apatite samples yielded young ages, low uranium content, and limited amounts of apatite; therefore, very few horizontal confined track lengths could be measured and the AFT data only provide information on the time when the samples cooled through $\sim 110^{\circ} \mathrm{C}$ (e.g. Reiners and Brandon, 2006).

\subsection{Provenance study of the IBR and Arakan Coast}


We analysed samples from the Inner (Paleogene) and Outer (Neogene) IBR, as well as the Arakan coastal region west of the IBR. We compared these data with published data from the IBR and CMB.

200

3.2.1. Detrital zircon $\mathrm{U}-\mathrm{Pb}$ and $\mathrm{Hf}$ isotope analysis.

202

8 samples were analysed for zircon U-Pb dating using the ICP-MS approach. All samples except the Triassic schist were then selected for Hf analyses.

204

205

\subsubsection{Detrital rutile U-Pb}

206

Rutile U-Pb analyses were carried out on 5 samples using the ICP-MS approach. A number of Eocene

207 samples contained no rutile.

208

3.2.3 Sr-Nd bulk analyses (mudstones).

Sr and Nd were separated from 13 mudstones using standard techniques, and analysed on a Thermo

211 Scientific Triton mass spectrometer at the BGS.

212

\subsubsection{Petrography and heavy minerals}

214 Fifteen IBR sandstones were point-counted by the Gazzi-Dickinson method (Ingersoll et al., 1984).

215 From the $63-250 \mu \mathrm{m}$ or 32-500 $\mu \mathrm{m}$ size fraction, 200-250 transparent heavy-minerals were counted by 216 the area method or point-counted, on a total of 19 samples from the IBR and CMB. 
219 Unreset zircon fission track data were used for provenance work, with analytical methods as described 220 in section 3.1.1.

\section{Results}

\subsection{Age elevation profiles}

\subsubsection{Zircon fission track results}

Of the samples analysed, we consider samples MY16-28A and MY16-14A to be partially reset; these two samples are thus relevant to the age elevation profiles and are discussed in this section, with data reported in SI 4. We consider all other samples to be unreset; these arediscussedin section 4.2.4 in terms of provenance information.

For MY16-28A, we interpret the ZFT ages to be partially reset, because the youngest population of crystals is younger than the depositional age (Fig. 2C) and by comparison with the samples' ZHe data, which we consider to be reset (see section 4.1 .2 below).

Low grade metamorphic sample MY16-14A is mapped as Triassic schist, consistent with its youngest zircon U-Pb population of $\sim 222 \mathrm{Ma}$ (section 2.2.1). This sample yielded 2 ZFT age populations, with peak ages of $97 \pm 14$ and $256 \pm 30$ Ma comprising $9 \pm 6 \%$ and $91 \pm 6 \%$ of the total number of grains, respectively. In general, crystals with younger ZFT ages have higher uranium contents (SI 4a), suggesting that these have accumulated significant radiation damage and hence have lower closure temperatures (Reiners and Brandon, 2006). Since one ZFT population is younger than the depositional age, and this sample has reset (Eocene) ZHe ages (see below), we interpret the sample as partially reset with respect to the ZFT system, representing slightly modified provenance ages. 


\subsubsection{ZHe results}

243

244

Reduced data are reported in SI 5. We report central ages calculated using the IsoplotR program with the Helioplot algorithm (Vermeesch, 2018) and uncertainties of 1 standard deviation. All cooling ages are based on 4-5 single-crystal aliquots. For 5 samples (MY16-14A, -18A, -21A, -28A, -30A) which appear to yield Cenozoic reset ages on the basis of being younger than depositional age, we excluded 1 or 2 outlier crystals and then calculated central ages (Fig. 2C; Table SI 5A). Within each sample, individual crystal sizes are similar and the range of effective Uranium is small (SI fig 5B). Therefore, we cannot use either of these characteristics, which can be related to closure temperature, to explain variations of single crystal ages (Guenthner et al., 2013). Large variations in provenance age could influence the amount of radiation damage that different crystals have accumulated; this likely explains scattered ages in these sandstone samples. Uranium zoning could potentially explain such age patterns (Hourigan et al., 2005), although zoning is rarely observed on zircons prints on the AFT external detectors. Only two crystals could be analyzed from sample MY16-35, which yielded ages of 17.8 and 50.3 Ma. The AFT age from this sample is $25.6 \mathrm{Ma}$ (see section 4.1 .3 below), suggesting that the younger ZHe age is incorrect. However, as there are no analytical criteria to evaluate whether one of these ZHe ages is correct, we disregard this ZHe sample. The 6 ages from sample MY16-34A are not as well-clustered as the other samples. The 4 youngest crystals range from 22.5 to $37.6 \mathrm{Ma}$, with a central age of $30.5 \pm 12.4 \mathrm{Ma}$ ( 2 sigma). Two crystals yield ages of 79.7 and $94.1 \mathrm{Ma}$, older than the mapped Paleogene depositional age. Therefore, unlike the other samples, this sample is only partially reset. Widely scattered single crystal ages can result from long residence in the partial retention zone. Samples MY16-37A and -38A have Triassic depositional ages. We discard an anomalously young Oligocene age and two relatively young ages from single crystals with eU>300 ppm. We report these unreset, detrital mean crystal ages of $256 \pm 26$ and $240 \pm 41$ Ma with errors of 1 standard deviation.

More detailed explanations for the age calculation of each sample are provided in SI 3.

\subsubsection{AFT results}


Ma, significantly younger than the depositional ages and ZHe ages, the samples are considered totally respectively. The former, MY16-31A, yields an extremely imprecise age of $30.3 \pm 10.7 \mathrm{Ma}$ and is not discussed further. of this sample is far younger than nearby samples. However, this sample is $16 \mathrm{~km}$ south of the next closest sample. Either the age is incorrect due to the difficulty of analysing such a low U-bearing sample or there is a structure in the valley between this sample and the rest of the profile. The latter proposal could explain the elevation of Mt Victoria, the highest peak in the IBR. However, as we cannot verify which is the correct explanation, we will not discuss this result further. Myanmar Basin

\subsubsection{Detrital zircon U-Pb with $H f$.}

Zircon U-Pb results (SI 7a and b, Fig 3):

Our U-Pb zircon data for the Eocene IBR are similar to previously published work (Allen et al., 2008; Naing et al., 2014). The signature is typified by strong peaks between 50 and $100 \mathrm{Ma}$, with subordinate older grains (peaks at $\sim 600 \mathrm{Ma}$ ). The youngest grain is usually around 40-45 Ma. The percentage of "arc type" grains, $<200 \mathrm{Ma}$, is highly variable but typically high, ranging between $~ 50->90 \%$. There is 
one outlying sample in the IBR, from Naing et al. (2014), which consists entirely of grains $>200$ Ma.

292

293

294

295

296

297

298

299

300

301

302

303

304

305

306

307

308

309

310

311

312

313

The 50-100 Ma populations are also present in the Neogene IBR samples, and whilst grains $<200 \mathrm{Ma}$ remain the dominant population in the south, grains $>400$ Ma dominate in the north (Allen et al., 2008), (MY05-3D and 10B; Fig 1B, SI1). These details are illustrated in the probability density plots shown in $\mathrm{SI} 7 \mathrm{~b}$.

Comparison of the IBR data with that of the CMB (SI 7b) (Licht et al., 2018; Oo et al., 2015; Robinson et al., 2014; Wang et al., 2014; Zhang et al., 2019) shows that in the Eocene, age spectra for the IBR and $\mathrm{CMB}$ are similar. For the Miocene, in the $\mathrm{CMB}$, the samples are similar to the Eocene samples, except that there are also younger peaks and the youngest grain is commonly in the range 20-30 Ma. This young population is not present in Miocene samples from the IBR. Furthermore, whilst the proportion of older grains (Precambrian and Palaeozoic) remains low in the CMB in Miocene rocks, it is variable in the IBR, becoming high in the northern region of study.

Fig 3 illustrates and summarises the above, showing that Eocene IBR and CMB samples are similar, whilst Neogene CMB samples differ from both the Neogene IBR and Eocene IBR and CMB samples.

\section{Hf composition of zircons (SI 7c, Fig 4).}

Our new and published (Naing et al., 2014) data from the IBR show that for Cretaceous-Paleogene zircons, $\varepsilon \mathrm{Hf}$ values are predominantly positive for both Eocene and Miocene samples, with a few grains with negative $\varepsilon H f$ values. This IBR signature contrasts with data from the CMB (Liang et al., 2008; Robinson et al., 2014; Wang et al., 2014; Zhang et al., 2019). In the CMB, Palaeocene to Eocene samples have Cretaceous-Paleogene zircons with overwhelmingly positive $\varepsilon H f$ values, similar to the signatures of coeval samples from the IBR. However, by the earliest Miocene, a high proportion of Cretaceous-Paleogene grains have negative $\varepsilon H f$ values in the CMB (Robinson et al., 2014; Wang et al., 2014; Zhang et al., 2019).

\subsubsection{Detrital rutile U-Pb (SI 8, Fig 5)}


All IBR samples, both Eocene and Miocene, show a strong peak of ages at ca. $500 \mathrm{Ma}$. In addition, there is a variable proportion of grains ranging between 50 and 200 Ma. Samples from the CMB (Zhang et al., 2019) are similar to those from the IBR in terms of the 500 Ma peak, and the 50-200 Ma grains, although the proportion of the latter population is higher in one CMB Eocene sample compared to approximately coeval samples in the IBR. However, the main difference between the IBR and CMB samples is the presence of $<40 \mathrm{Ma}$ grains in Miocene rocks of the CMB. Such ages are absent from Miocene samples of the IBR.

Building on, and in agreement with previous work (Allen et al., 2008), the Eocene rocks of the IBR have $\varepsilon N d(0)$ values more positive than -5 , coupled with ${ }^{87} \mathrm{Sr} /{ }^{86} \mathrm{Sr}$ values $<0.711$ suggestive of considerable contribution from a juvenile source region. The Miocene rocks have a highly variable signature trending to more negative $\varepsilon N d(0)$ values and higher ${ }^{87} \mathrm{Sr} /{ }^{86} \mathrm{Sr}$ "crustal" values than Eocene rocks. Eocene fore-arc rocks of the CMB have similar values to those of the IBR. Similar to the IBR, the Miocene rocks of the $\mathrm{CMB}$ trend to more crustal values, but they do not reach the same values as those of the IBR (Colin et al., 1999; Licht et al., 2013; Licht et al., 2014; Zhang et al., 2019).

\subsubsection{Detrital zircon fission track dating (SI 4, Table 1).}

Combining previous work (Allen et al., 2008) with current work for the IBR shows that both Eocene and Miocene rocks have Palaeocene, Cretaceous and Carboniferous ZFT populations. The Miocene rocks differ from the Eocene rocks in their additional late Oligocene population. The mid Mio-Pliocene sample has an additional 6 Ma population.

There are insufficient data from the $\mathrm{CMB}$ to make a robust comparison between $\mathrm{CMB}$ and IBR rocks for the Eocene period. The one Eocene sample available from the CMB has grain ages similar to the spectra seen in the IBR. Miocene CMB rocks differ from Miocene rocks of the IBR in their absence of populations with ZFT ages $>100 \mathrm{Ma}$ and their occurrence of populations with ages $<20 \mathrm{Ma}$. 
Eocene samples from the IBR are mainly litho-feldspatho-quartzose, plagioclase-rich; lithic fragments are commonly to dominantly microlitic, and subordinately felsitic volcanic, medium-rank metamorphic and sedimentary (mostly chert) (Fig 7A and B). This composition indicates arc-derived provenance with a significant recycled / substrate component. Neogene IBR samples are variable in composition. They are quite similar to Eocene samples, being mainly litho-feldspatho-quartzose and feldspatho-litho-quartzose. Compared to Eocene sandstones, the Neogene samples show an increase in volcanic and/or metamorphic lithic fragments at the expense of sedimentary lithics. al., 2015; Wang et al., 2014; Zhang et al., 2019) shows that rocks of both the CMB and IBR contain significant arc-derived detritus in the Eocene. However, the evolution away from the $L$ pole on the QFL plot, and the transition away from the Lv pole on the lithics plot, from Eocene into the Neogene in the $\mathrm{CMB}$, is not replicated in the IBR. Dense minerals (Fig $7 \mathrm{C}$ ) show, as expected, a decrease in diagenetic influence through time, from dominance of durable ZTR minerals from Eocene to Miocene times, preservation of epidote retained in the upper Miocene-Pliocene, and amphibole preserved only in the modern-day sediment.

\section{Interpretations}

5.1. Timing of IBR uplift as determined from the low temperature thermochronological ageelevation profiles

A traditional tool for interpreting thermochronologic data from elevation profiles is an age versus elevation plot. Because the profile crosses two fault zones (Fig. 2A), the samples are divided into 3 groups: West of and within the Lelon fault zone ( $\sim 30 \mathrm{~km}$ wide); the IBR core ( $\sim 10 \mathrm{~km}$ wide); and in the 
Kabaw fault zone ( $8 \mathrm{~km}$ wide). Figure $8 \mathrm{~A}$ shows the AFT, ZHe, and ZFT data, color-coded with respect to the location of major structures shown in Figure 2.

The relationship between AFT and ZHe ages can be difficult to resolve on an age versus elevation plot. Plotting different thermochronometers on a pseudovertical profile (after Reiners et al., 2003) provides a direct way of visualizing all of the data (Fig. 8B). ZHe data points are shifted vertically by $3.5 \mathrm{~km}$ (see Fig. 8 for explanation) to correspond to the elevation that they would have had when the sample cooled through the AFT closure temperature. Two partially reset ZFT samples, MY16-14A and -28A (section 4.1.1), are not plotted, as it is unclear what temperature they experienced.

Paleogene IBR samples collected within or west of the Lelon dextral transpressive shear zone (Figs. $2 \mathrm{~A}, \mathrm{C}, 8 \mathrm{~A}, \mathrm{~B}$, blue path) record a young cooling history. Plotting the 3 consistent AFT ages and the 3 young ZHe ages from west of the Lelon Fault zone together (Fig. 8B, blue path) shows rapid exhumation between about $\sim 20$ and 14 Ma. Clearly the highest elevation, $30.5 \pm 12.4$ Ma partially reset (section 4.1.2) ZHe age (MY16-34) is incompatible with such rapid exhumation. Therefore, we suggest that the base of the ZHe partial retention zone (PRZ) lies at an elevation of $\sim 2500 \mathrm{~m}$ (Fig. 8A). In turn, this implies that the change in slope of the blue age-elevation profile, roughly defining the onset of rapid exhumation of the footwall, lies at about 19-23 Ma, around the Oligocene - Miocene boundary. This estimate neglects the effect of advection, which would suggest that rapid exhumation began slightly earlier (Brown and Summerfield, 1997).

The 3 IBR core AFT samples from east of the Lelon Fault have ages similar to the western segment and can be plotted along a similar trend as the 3 AFT samples from the blue path (Fig. 8B, green and blue paths). Since the Lelon Fault has young strike-slip motion, motion on the Lelon Fault and another westvergent fault farther to the west caused synchronous mid Miocene cooling and then the two blocks were transposed next to each other. 
Samples MY16-14A and MY16-18A, with ZHe ages of $39.8 \pm 2.0 \mathrm{Ma}$ and $30.3 \pm 9.2 \mathrm{Ma}$, respectively, were collected from Triassic schist in the core of the IBR, east of the Lelon Fault zone (Fig. 8B, green path). One can propose at least 2 scenarios to explain the Eocene ZHe ages (MY16-14A and MY1618A). One possibility is that the IBR core experienced at least $1 \mathrm{~km}$ of exhumation during the Eocene, starting prior to $39.8 \pm 2.0 \mathrm{Ma}$ (the age of the fully reset ZHe sample). Cooling paused in the late Eocene-Oligocene (Fig. 8B, solid green path). Alternatively, if sample MY16-14A is partially rather than fully reset (Fig. 8B, dashed green path), then the Eocene history only represents residence within the ZHe partial retention zone. The age-elevation profile cannot distinguish between these possibilities. The western, partially reset ZHe sample is younger than the eastern sample, suggesting that the former sample cooled more recently although it lies $867 \mathrm{~m}$ higher (Fig. 2). As the samples lie $10 \mathrm{~km}$ apart, we suggest that this inverted age pattern may be explained by differential exhumation within the IBR core. The younger, partially reset Eocene sample (MY16-18A), which is closer to the Lelon Fault, reflects a deeper Eocene structural level, suggesting that the west-vergent Lelon Fault caused more exhumation than the east-vergent Kabaw fault.

The ZHe ages of $256 \pm 52$ and $240 \pm 81 \mathrm{Ma}$ from the eastern margin of the core of the IBR, within the Kabaw fault zone (Figure 8B, red path), are similar to the Triassic maximum depositional age, implying that these samples have not been exposed to temperatures of over $\sim 150^{\circ} \mathrm{C}$ since that time. The three AFT ages overlap with each other within error, ranging from $23.6 \pm 8.2$. Ma to $32.7 \pm 4.4 \mathrm{Ma}$. These AFT samples have lower $U$ content and hence less precise ages than samples collected from farther to the west. According to the structural map of Maurin and Rangin (2009b) (Figure 2A), the eastern samples lie in several fault slivers and some may even lie east of the east-vergent Kabaw fault system. However, this interpretation may be an artifact of the limited resolution of the map. Exhumation commenced prior to roughly 28-32 Ma. In comparison with the results from the core of the IBR, the eastern flank of the IBR experienced less exhumation. 

interpretations.

411

412

In agreement with previous work (Allen et al., 2008; Naing et al., 2014), we consider the Eocene sedimentary rocks of the IBR to be derived predominantly from the Myanmar magmatic arc to the east, rather than off-scraped Himalayan-derived Bengal Fan material as earlier work proposed (Curray, 2005). This conclusion is based on the more arc-like provenance signature of the Eocene IBR rocks compared to coeval Himalayan-derived material of the Himalayan foreland basin and onshore Bengal Basin, as expressed by petrography, $\varepsilon N d$ values and proportions of arc-derived Mesozoic-Paleogene zircons (e.g. cf data from DeCelles et al., 2004; Najman et al., 2008). Instead, Eocene IBR detrital characteristics are similar to those from the Wuntho-Popa arc in terms of positive $\varepsilon \mathrm{Hf}$ values of zircons (Zhang et al., 2017b). Additional contribution from older crustal material, potentially from the Burmese "basement" or from trench sediment input from the west, is indicated by, for example, the presence of Palaeozoic and older rutiles and zircons. Given the similarity of Eocene data between the IBR and the CMB (section 4), also interpreted as Myanmar-arc derived (Licht et al., 2013; Licht et al., 2014; Zhang et al., 2019), we consider that during deposition of the Eocene rocks (dated at mid Eocene; section 2.2.1), the IBR was not yet uplifted above sea level, and the Myanmar arc supplied detritus westward to the ocean.

In the $\mathrm{CMB}$, an influx of rutiles with Cenozoic U-Pb ages (Fig. 5), and Cretaceous-Paleogene zircons with negative $\mathrm{\varepsilon Hf}$ values (Figs. 3 and 4) first occurred sometime between the late Eocene and mid Oligocene, reaching significant proportions by latest Oligocene. This is interpreted as the result of influx from the exhuming Mogok Metamorphic Belt and spatially associated granites of the Irrawaddy River uplands, as the river emerged as a major through-flowing drainage (Zhang et al., 2019). This interpretation is consistent with the shift to more negative $\varepsilon N d$ values (Fig. 6), a higher proportion of metamorphic detritus (Fig. 7), and Neogene zircon U-Pb and FT ages (Fig 3 and Table 1). By contrast, in the Miocene IBR sedimentary rocks, there is no clear influx of detrital zircons with negative $\varepsilon \mathrm{Hf}$ 
values or Neogene fission track ages, nor rutiles with Neogene U-Pb ages. This indicates that the Irrawaddy River did not supply this region, from which we interpret that the IBR was uplifting and forming a barrier to the west by this time. This is consistent with the age elevation data (section 5.1), and the argument that the IBR needed to have positive relief to form the western flank of the Irrawaddy river system.

The similarity in some aspects of the IBR signatures between Eocene and Miocene samples may be explained by exhumation of the IBR by the Miocene; thus Miocene rocks contain detritus recycled from the Eocene rocks of the IBR. However, there is also an additional component of detritus to the Miocene IBR rocks which is not present in the Eocene or older (e.g. Triassic) IBR. This component is most clearly seen in the northern part of the studied area where Neogene IBR rocks (MY05-2A, 3D, 10B; Table 1) have ZFT ages with a late Oligocene population. Contribution from an additional source is also evidenced in the shift in provenance indicated by the trends seen in the $\mathrm{Sr}-\mathrm{Nd}$ and petrographic data between Eocene and Miocene IBR rocks. In agreement with the conclusion of Allen et al. (2008), we suggest that Neogene IBR rocks, at least in the northern part of the study area, contain a component of Himalayan-derived material, delivered to the region as off-scraped Bengal Fan.

\subsection{Mechanisms of formation of the IBR}

Licht et al. (2018) summarised a number of models that have been proposed to explain the uplift of the range, namely: a change in angle of the subducting slab; the accretion of an arc or small terrane; a change of Indian Plate kinematics with respect to Southeast Asia, potentially also involving collision of the Indian Plate with the Burma Plate followed by a change in plate motion vectors; the result of the evolution of the prism in a hyper-oblique setting; or, for the Neogene only, IBR evolution reflecting the effects of Tibetan plateau collapse and subsequent westward crustal flow. To the above list we also note the previous proposals that the IBR may have evolved due to collision with the 90 East Ridge (Maurin and Rangin, 2009a) or may result from transmission of stress resulting from large clockwise rotations recorded in the Sibumasu Block between Eocene and mid Miocene times (Li et al., 2018). 
The most significant signal in our results is the episode of exhumation at the Oligo-Miocene boundary. We suggest this period of exhumation could result from a change in the dynamics of the range. Accretionary wedges are generally thought to grow in a self-similar manner, increasing their volume whilst keeping surface and basal slopes constant (e.g. Dahlen, 1990). Changes in climate, resulting in changes in the amount of erosion, can perturb accretionary wedges, resulting in changes to range widths and exhumation rates (e.g. Whipple, 2009 and references therein). However, no major climate transitions are known in the Myanmar region during the episode of exhumation at ca $20 \mathrm{Ma}$. Changes in plate motion vectors between the Indian and Asian plates can be discounted as a possible cause of IBR exhumation, since no such changesare detectable above the errors in the rotation poles (e.g. van Hinsbergen et al., 2011). Another potential cause of a perturbation to the steady self-similar growth of an accretionary wedge is changing the rate of sediment input into the range. Increases in the thickness of the incoming sedimentary pile can cause significant changes in the uplift and deformation of fold-thrust belts by changing the relative balance between the rate of input of material into the range and the forces resulting from gravity acting on the elevation contrast between the mountains and lowlands (Ball et al., 2019). In this situation, the size of the perturbation depends upon the rate and magnitude of the change in input sediment thickness, and the material properties of the range (Ball et al., 2019). There was a dramatic increase in the supply of sediment to the Bengal fan starting around the Oligo-Miocene boundary times (Krishna et al., 2016), and the Miocene is the earliest recorded time that Bengal Fan-derived material was accreted to the IBR (Allen et al., 2008). The arrival of thick sediments of the Bengal Fan into the subduction zone is therefore a likely cause of the exhumation around the time of the Oligo-Miocene boundary. Incorporation of these sediments into the fold-thrust belt may have led to a kinematic reorganisation of the over-riding plate, as suggested by the early Miocene onset of spreading in the Andaman Sea (e.g. Curray, 2005) which is kinematically linked to the Sagaing Fault, by the Miocene switch from transtension to transpression in the CMB (Pivnik et al., 1998), and by the late Oligocene period of uplift proposed for the Myanmar arc (Zhang et al., 2017b). 
Our data also hints at a possible period of exhumation at or before the late Eocene. During most of the Eocene, the rate of convergence between India and Asia rapidly decreased (e.g. van Hinsbergen et al., 2011), thought to be due to the increased resistive forces generated by continental collision and mountain building in Asia. At a similar time ( $36.5 \mathrm{Ma}$ Jacob et al., 2014), the Wharton spreading ridge, which separated the Australian and Indian plates in the NE Indian Ocean, was abandoned. These region-wide reorganisations in plate motions, and therefore the forces transmitted through the lithosphere in these plates and in the surrounding areas, may have caused the potential Eocene exhumational phase in the Indo-Burman Ranges. Any such changes could potentially provide an equally plausible mechanism for Paleogene IBR exhumation as the already published proposals outlined above. However, our lack of knowledge of the detailed kinematics of the Asian margin during Eocene times makes the details of the mechanisms difficult to establish.

\section{Summary and Conclusions}

Mid Eocene rocks of the Central Myanmar Basin and Indo-Burman Ranges were derived from the same local eastern Myanmar arc source, with subordinate input from a more crustal source, potentially either Myanmar "basement" or westerly-derived trench sediment. The region west of the Myanmar arc was therefore open to the ocean at this time and the IBR was not yet uplifted sufficiently to provide a barrier to influx of detritus from the east. ZHe data from samples along the IBR core profile may suggest that exhumation of the IBR commenced prior to late Eocene; AFT data from the Kabaw fault zone profile may suggest exhumation was active by the latest Eocene. Although we tentatively consider that Eocene exhumation did occur, the thermochronologic data are weak; therefore this conclusion remains open to reinterpretation in light of future work. consistent with provenance data which shows that the IBR provided sufficient topography to (1) 
constrain the nascent Irrawaddy River and (2) act as a barrier to the river delivering sediment further west, in the Paleogene. Thus, whilst Miocene rocks of the Central Myanmar Basin reflect an Irrawaddy provenance, approximately co-eval rocks of the IBR reflect input of detritus recycled from the uplifting IBR as well as Himalayan-derived input off-scraped from the Bengal Fan.

A number of viable models for the evolution of the IBR have been previously proposed to which we now add the idea that changes in sediment thickness input to the system at the trench may have resulted in the uplift event at the Oligo-Miocene boundary.

\section{Acknowledgements}

This work was funded by the Chevron Corporation. Particular thanks are due to Kila Bale and Robert Corley (Chevron Asia Pacific Exploration \& Production Company) who provided samples from the Arakan region and supported the early stages of this project, while Lawrence Febo and Rebecca Hackworth (Chevron Energy Technology Company) contributed biostratigraphic interpretation. Santa Maria Tours and Travels, Yangon, in particular Mya Min Din (Moe) and Zaw Win Htwe, provided excellent field logistical support. This paper was considerably improved by the detailed reviews from Alexis Licht and an anonymous reviewer. We dedicate this paper to the memory of our co-author, Dr. Gwladys Govin.

\section{List of Supplementary Items}

1: sample location information. (A) table, (B), Google Earth kmz file.

2: biostratigraphic data.

3: analytical methods.

4: ZFT data. (A) data table, (B) radial plots for samples used in the age elevation profiles, (C) Radial plots for samples used for provenance. (C) includes published data, as follows: ( ${ }^{1}$ prefix MY05, from 
532 Allen et al., 2008), compared to published data from the CMB ( ${ }^{2}$ Zhang et al., 2019). Our new data are highlighted with an asterisk.

5: ZHe data. (A) data table, 5 B) Plots of ZHe age versus effective uranium (eU) and alpha ejection correction (Ft), 5 C) IsoplotR Helioplot output plots (Vermeesch, 2018) for reset ZHe samples. Single crystal outliers are not included in the calculations and are shown as unfilled circles on the plots. 6: AFT data: (A) - summary of data; (B) - full data set; (C) - radial plots. 7. Zircon U-Pb data (A), probability density plots for the IBR and Central Basin (B), with Hf data (C). For the probability plots ( $\mathrm{SI} \mathrm{7b}$ ) Data from the $\mathrm{CMB}$ rocks and Irrawaddy modern river sand from: ${ }^{1}$ Wang et al. (2014) and Licht et al. (2018), ${ }^{2}$ Robinson et al. (2014), ${ }^{3}$ Licht et al. (2018), ${ }^{4}$ Zhang et al. (2019), ${ }^{5}$ Wang et al. (2014), ${ }^{6}$ Liang et al. (2008), ${ }^{7}$ Bodet and Scharer (2000) and Garzanti et al. (2016). Data from the IBR includes previously published work ( ${ }^{1}$ samples labelled with prefix MY05 are from Allen et al. (2008); ${ }^{2}$ samples labelled with prefix 10TTN are from Naing et al. (2014), all other samples (prefix MY16 and R16) are from this study, and are identified with an asterisk). Note that the geological map of the Burma Earth Sciences Research Division (1977) does not record Oligocene rocks in the area of Naing's IBR study: instead, samples 10TTN-10 and 13 are designated Eocene and 10TTN-16 and 20 are designated Miocene. Colour coding represents different time intervals - see Fig 3.

9. Sr-Nd bulk data. 10. Petrography $(A)$ and heavy mineral $(B)$ data.

Table 1: summary of zircon fission track data used for provenance determination including previously published data ( ${ }^{1}$ prefix MY05, from Allen et al., 2008), compared to published data from the CMB ('Zhang et al., 2019) (B). Our new data are highlighted with an asterisk. Corresponding radial plots, including those for samples where clear peaks were not defined, are shown in SI 4c. 
Fig 1A: Simplified geological map of Burma, adapted from Robinson et al. (2014) and (B), from (Burma Earth Sciences Research Division, 1977) showing the locations of our sampling sites.

Fig. 2. A) Location of age-elevation thermochronologic samples superposed on structural observations from Maurin and Rangin (2009b) and Zhang et al. (2017a), located in context on Fig 1B. B) East-west oriented topographic swath profile, based on SRTM data. Location of $37 \mathrm{~km}$ wide topographic swath are shown by white box in A. Elevation of individual samples are marked with crosses. C) Thermochronologic ages projected onto east-west-oriented transect. Sample numbers are marked. ZFT peak ages of populations denoted by stars. ZHe single crystal ages with standard errors are denoted by small squares; greyed markers are considered outliers and are not used in the calculation of sample ages. Large squares denote ZHe central ages calculated using IsoplotR; 1 sigma error bars are shown. AFT data (diamonds) are shown with 1 sigma error bars.

Fig 3: Multi-dimensional Scaling (MDS) plot (Vermeesch, 2018) showing similarity in zircon U-Pb ages between samples of the Eocene IBR and CMB, and difference of the Neogene CMB from both the Neogene IBR and Paleogene IBR and CMB. Our new data shown with symbols in bold outline. Published data from Wang et al. (2014), Licht et al. (2018), Robinson et al. (2014), Zhang et al. (2019), Liang et al. (2008), Bodet and Scharer (2000) and Garzanti et al. (2016) for the Central Myanmar Basin, and from Allen et al. (2008) and Naing et al. (2014) for the IBR. Probability density plots for individual samples are given in SI 7b.

577 Fig 4: (A) Detrital zircon U-Pb vs $\varepsilon H f(t)$ data for the IBR, from this study (samples prefix MY16 and R16, highlighted with an asterisk) and from previously published data ( ${ }^{1}$ sample prefix TTN, denoted by grey symbols, from Naing et al. (2014)). Note that samples from Naing et al. TTN10 and TTN13 are attributed to Oligocene by those authors, but Eocene according to the map of the Burma Earth 

Scharer (2000), ${ }^{3}$ Zhang et al. (2019), 'Liang et al. (2008), (Wang et al., 2014), Zhang et al. (2019), Robinson et al. (2014), ${ }^{5}$ Robinson et al. (2014), Zhang et al. (2019), ${ }^{6}$ (Wang et al., 2014), Zhang et al. (2019). (C) A compilation of potential source regions (see Fig 1), showing the similarity between data from the Miocene $\mathrm{CMB}$ and the Mogok Metamorphic Belt and spatially associated granites of the Irrawaddy headwaters (modified from Zhang et al. (2019) and references therein).

Fig 5. Detrital rutile $\mathrm{U}-\mathrm{Pb}$ data from the IBR (A), and samples from the $\mathrm{CMB} .{ }^{1} \mathrm{CMB}$ data and figure modified from Zhang et al. (2019). Our new data highlighted with asterisks. Data with 207Pb/206Pb $>0.5$ were excluded. Colour coding relates to sample ages.

Fig 6: Sr-Nd bulk data from the IBR compared to published data from co-eval rocks from the CMB, as referenced in legend.

Fig 7. Sandstone petrography and heavy mineral data from the IBR and $C M B$ (CMB petrographic data from Zhang et al. (2019)). Compositional fields in the QFL plot (8A) after Garzanti (2019). Data from modern Irrawaddy sand after Garzanti et al. (2016). Q= quartz; F= feldspar; L= lithic fragments (Lm= metamorphic; LV= volcanic; Ls= sedimentary). In the compositional biplot (8C) (Gabriel, 1971), both multivariate observations (points) and variables (rays) are displayed. The length of each ray is proportional to the variance of the corresponding element in the data set. If the angle between two rays is close to $0^{\circ}, 90^{\circ}$, or $180^{\circ}$, then the corresponding elements are directly correlated, uncorrelated, or inversely correlated, respectively.

Fig 8. Thermochonologic data. Blue, green and red symbols correspond to position of samples west and within the Lelon Fault zone, in the IBR core, and in the Kabaw Fault zone, respectively. A) Ageelevation plot showing ZHe central ages with 2 sigma error bars (squares) and AFT pooled ages with 1 sigma error bars (diamonds). Mesozoic detrital ZHe ages are plotted as single crystals. B) Pseudovertical profiles (after Reiners et al., 2003) showing ZHe data shifted vertically by $3.5 \mathrm{~km}$ with 

red cooling paths are discussed in the text.

\section{References}

Acharyya, S.K., 2015. Indo-Burma Range: a belt of accreted microcontinents, ophiolites and Mesozoic-Paleogene flyschoid sediments. International Journal of Earth Sciences 104, 1235-1251. Allen, R., Najman, Y., Carter, A., Parrish, R., Bickle, M., Paul, M., Garzanti, E., Reisberg, L., Chapman, H., Vezzoli, G., Ando, S., 2008. Provenance of the Tertiary sedimentary rocks of the Indo- Burman Ranges, Burma (Myanmar): Burman arc or Himalayan-derived? . Journal of the Geological Society London 165, 1045-1057. thin-skinned fold-thrust belts, and applications to the Makran accretionary prism and Indo-Burman Ranges. Geophysical Journal International doi: 10.1093/gji/ggz139, .

Barley, M.E., Pickard, A.L., Zaw, K., Rak, P., Doyle, M.G., 2003. Jurassic to Miocene magmatism and metamorphism in the Mogok metamorphic belt and the India-Eurasia collision in Myanmar.

\section{Tectonics 22.}

Bender, F., 1983. Geology of Burma. Borntraeger, Berlin.

Bertrand, G., Rangin, C., 2003. Tectonics of the western margin of the Shan plateau (central Myanmar): implication for the India-Indochina oblique convergence since the Oligocene. Journal of Asian Earth Sciences 21, 1139-1157.

Betka, P.M., Seeber, L., Thomson, S.N., Steckler, M.S., Sincavage, R., Zoramthara, C., 2018. Slippartitioning above a shallow, weak decollement beneath the Indo-Burman accretionary prism. Earth and Planetary Science Letters 503, 17-28.

Bodet, F., Scharer, U., 2000. Evolution of the SE-Asian continent from U-Pb and Hf isotopes in single grains of zircon and baddeleyite from large rivers. Geochimica Et Cosmochimica Acta 64, 2067-2091. Brown, R.W., Summerfield, M.A., 1997. Some uncertainties in the derivation of rates of denudation from thermochronologic data. Earth Surface Processes and Landforms 22, 239-248.

Brunnschweiler, R.O., 1966. On the geology of the Indoburman ranges. Journal of the Geological Society, Australia. 13, 137-194.

Burma Earth Sciences Research Division, B., 1977. Geological map of the Socialist Republic of the Union of Burma, 1:1000000. Security Printing Works, Burma, Burma.

Colin, C., Turpin, L., Bertaux, J., Desprairies, A., Kissel, C., 1999. Erosional history of the Himalayan and Burman ranges during the last two glacial-interglacial cycles. Earth and Planetary Science Letters $171,647-660$.

Curray, J., 2014. The Bengal Depositional System: From rift to orogeny. Marine Geology 352, 59-69. Curray, J.R., 2005. Tectonics and history of the Andaman Sea region. Journal of Asian Earth Sciences 25, 187-232.

Dahlen, F.A., 1990. Critical taper model of fold-and-thrust belts and accretionary wedges. Annural Reviews of Earth and Planetary Science 18, 66-99.

DeCelles, P.G., Gehrels, G.E., Najman, Y., Martin, A.J., Garzanti, E., 2004. Detrital geochronology and geochemistry of Cretaceous-Early Miocene strata of Nepal: Implications for timing and diachroneity of initial Himalayan orogenesis. Earth and Planetary Science Letters 227, 313-330. 
Gabriel, K.R., 1971. The biplot graphic display of matrices with application to principal component 650 analysis. . Biometrika 58, 453-467.

Garzanti, E., 2019. Petrographic classification of sand and sandstone. Earth Science Reviews 190, https://doi.org/10.1016/j.earscirev.2018.1012.1014. Garzanti, E., Wang, J.-G., Vezzoli, G., Limonta, M., 2016. Tracing provenance and sediment fluxes in the Irrawaddy River Basin (Myanmar). Chemical Geology doi: 10.1016/j.chemgeo.2016.06.010. Guenthner, W.R., Reiners, P.W., Ketcham, R.A., Nasdala, L., Giester, G., 2013. Helium diffusion in natural zircon: Radiation damage, anisotropy, and the interpretation of zircon (U-Th)/He thermochronology. American Journal of Science 313, 145-198. Hourigan, J.K., Reiners, P.W., Brandon, M.T., 2005. U-Th zonation-dependent alpha-ejection in (UTh)/He chronometry. Geochimica et Cosmochimica Acta 69, 3349-3365. Ingersoll, R.V., Bullard, T.F., Ford, R.L., Grimm, J.P., Pickle, J.D., Sares, S.W., 1984. The effect of grainsize on detrital modes: A test of the Gazzi-Dickinson point-counting method. Journal of Sedimentary Petrology 54, 103-116.

Jacob, J., Dyment, J., Yatheesh, V., 2014. Revisiting the structure, age, and evolution of the Wharton Basin to better understand subduction under Indonesia. Journal of Geophysical Research-Solid Earth $119,169-190$.

Krishna, K.S., Ismaiel, M., Srinivas, K., Gopala, D., Mishra, J., Saha, D., 2016. Sediment pathways and emergence of Himalayan source material in the Bay of Bengal. Current Science 110, 363-372.

Li, S.H., van Hinsbergen, D.J.J., Deng, C.L., Advokaat, E.L., Zhu, R.X., 2018. Paleomagnetic Constraints From the Baoshan Area on the Deformation of the Qiangtang-Sibumasu Terrane Around the Eastern Himalayan Syntaxis. Journal of Geophysical Research-Solid Earth 123, 977-997. Liang, Y.-H., Chung, S.L., Liu, D., Xu, Y., Wu, F.Y., Yang, J.H., Wang, Y., Lo, C.H., 2008. Detrital zircon evidence from Burma for reorganisation of the eastern Himalayan drainage system. American Journal of Science 308, 618-638. Licht, A., Dupont-Nivet, G., Win, Z., Swe, H.H., Kaythi, M., Roperch, P., Ugrain, T., Littell, V., Park, D., Westerweel, J., Jones, D., Poblete, F., Aung, D.W., Huang, H., Hoorn, C., Sein, K., 2018. Paleogene evolution of the Burmese forearc basin and implications for the history of India-Asia convergence. Geological Society of America Bulletin doi.org/10.1130/B35002.1.

Licht, A., France-Lanord, C., Reisberg, L., Fontaine, C., Soe, A.N., Jaeger, J.J., 2013. A palaeo TibetMyanmar connection? Reconstructing the Late Eocene drainage system of central Myanmar using a multi-proxy approach. Journal of the Geological Society 170, 929-939.

Licht, A., Reisberg, L., France-Lanord, C., Naing Soe, A., Jaeger, J.J., 2014. Cenozoic evolution of the central Myanmar drainage system: insights from sediment provenance in the Minbu sub-basin. Basin Research 28, 237-251.

Liu, C.-Z., Chung, S.-L., Wu, F.-Y., Zhang, C., Xu, Y., Wang, J.-G., Chen, Y., Guo, S., 2016. Tethyan suturing in Southeast Asia: Zircon $\mathrm{U}-\mathrm{Pb}$ and $\mathrm{Hf}-\mathrm{O}$ isotopic constraints from Myanmar ophiolites. Geology 44, 311-314.

Maurin, T., Rangin, C., 2009a. Impact of the 90 degrees E ridge at the Indo-Burmese subduction zone imaged from deep seismic reflection data. Marine Geology 266, 143-155.

Maurin, T., Rangin, C., 2009b. Structure and kinematics of the Indo-Burmese Wedge: Recent and fast growth of the outer wedge. Tectonics 28, TC2010, doi: 2010.1029/2008TC002276.

Mitchell, A.H.G., 1993. Cretaceous-Cenozoic tectonic events in the western Myanmar (Burma)Assam region. Journal of the Geological Society, London 150, 1089-1102.

Mitchell, A.H.G., Chung, S.-L., Thura, O., Lin, T.-S., Hung, C.-H., 2012. Zircon U-Pb ages in Myanmar:magmatic-metamorphic events and the closure of a Neotethys ocean? Journal of Asian Earth Sciences 56, 1-23.

Naing, T.T., Bussien, D.A., Winkler, W.H., Nold, M., Von Quadt, A., 2014. Provenance study on Eocene-Miocene sandstones of the Rakhine Coastal Belt, Indo-Burman Ranges of Myanmar: geodynamic implications, in: Scott, R.A., Smyth, H.R., Morton, A.C., Richardson, N. (Eds.), Sediment Provenance Studies in Hydrocarbon Exploration and Production, pp. 195-216. 
Najman, Y., Allen, R., Willett, E.A.F., Carter, A., Barford, D., Garzanti, E., Wijbrans, J., Bickle, M., vezzoli, G., Ando, S., Oliver, G., Uddin, M., 2012. The record of Himalayan erosion preserved in the sedimentary rocks of the Hatia Trough of the Bengal Basin and the Chittagong Hill Tracts, Bangladesh. Basin Research 24, 499-519.

Najman, Y., Bickle, M., BouDagher-Fadel, M., Carter, A., Garzanti, E., Paul, M., Wijbrans, J., Willett, E., Oliver, G., Parrish, R., Akhter, S.H., Allen, R., Ando, S., Chisty, E., Reisberg, L., Vezzoli, G., 2008. The Paleogene record of Himalayan erosion: Bengal Basin, Bangladesh. Earth and Planetary Science Letters 273, 1-14.

Oo, K.L., Zaw, K., Meffre, S., Myiyya, Aung, D.W., Lai, C.-K., 2015. Provenance of the Eocene sandstones in the southern Chindwin Basin, Maynamar: Implications for the unroofing history of the Cretaceous-Eocene magmatic arc. Journal of Asian Earth Sciences 107, 172-194.

Pivnik, D.A., Nahm, J., Tucker, R.S., Smith, G.O., Nyein, K., Nyunt, M., Maung, P.H., 1998. Polyphase deformation in a fore-arc/back-arc basin, Salin subbasin, Myanmar (Burma). Aapg Bulletin 82, 18371856.

Rangin, C., Maurin, T., Masson, F., 2013. Combined effects of Eurasia/Sunda oblique convergence and East-Tibetan crustal flow on the active tectonics of Burma. Journal of Asian Earth Sciences 76, 185-194.

Reiners, P., Zhou, Z., Ehlers, T.A., Xu, C., Brandon, M., Donelick, R.A., Nicolescu, S., 2003. Postorogenic evolution of the Dabie-Shan, eastern China, from (U-Th)/He and fission-track thermochronology. American Journal of Science 303, 489-518.

Reiners, P.W., Brandon, M.T., 2006. Using thermochronology to understand orogenic erosion. Annual Review of Earth and Planetary Sciences 34, 419-466.

Ridd, M.F., Racey, A., 2015a. Onshore petroleum geology of Myanmar: Central Burma Depression, in: Racey, A., Ridd, M.F. (Eds.), Petroleum Geology of Myanmar. Geological Society of London Memoirs, London, pp. 21-50.

Ridd, M.F., Racey, A., 2015b. Regional tectonic setting of Myanmar's petroleum basins., in: Racey, A., Ridd, M.F. (Eds.), Petroleum Geology of Myanmar. Geological Society of London, Memoirs, pp. 7-12. Robinson, R.A.J., Brezina, C.A., Parrish, R.R., Horstwood, M.S.A., Oo, N.W., Bird, M.I., Thein, M., Walters, A.S., Oliver, G.J.H., Zaw, K., 2014. Large rivers and orogens: The evolution of the Yarlung Tsangpo-Irrawaddy system and the eastern Himalayan syntaxis. Gondwana Research 26, 112-121. Sevastjanova, I., Hall, R., Rittner, M., Paw, S., Naing, T.T., Alderton, D.H., Comfrt, G., 2015. Myanmar and Asia United, Australia left behind long ago. Gondwana Research in press.

Society, M.G., 2017. Geological map of Myanmar. Geological Society of London Memoirs 48. Socquet, A., Goffe, B., Pubellier, M., Ragin, C., 2002. Le metamorphism Tardi-Cretace a Eocene des zones internes de la chaine Indo-Birmane (Myanmar occidental):implications geodynamiques. C.R. Geoscience 334, 573-580.

Suzuki, H., Maung, M., Aye, K.A., Takai, M., 2004. Jurassic radiolarian from chert pebbles of the Eocene Pondaung Formation, Central Myanmar. Neues Jahrbuch fur Geologie und Palaontologie 231, 369-393.

van Hinsbergen, D.J.J., Steinberger, B., Doubrovine, P.V., Gassmoller, R., 2011. Acceleration and deceleration of India-Asia convergence since the Cretaceous: Roles of mantle plumes and continental collision. Journal of Geophysical Research-Solid Earth 116.

Vermeesch, P., 2018. IsoplotR: a free and open toolbox for geochronology. Geoscience Frontiers 9 , 1479-1493.

Wang, J.G., Wu, F.Y., Tan, X.C., Liu, C.Z., 2014. Magmatic evolution of the Western Myanmar Arc documented by $\mathrm{U}-\mathrm{Pb}$ and $\mathrm{Hf}$ isotopes in detrital zircon. Tectonophysics 612, 97-105.

Whipple, K.X., 2009. The influence of climate on the tectonic evolution of mountain belts. Nature Geoscience 2, 97-104.

Zhang, J., Xiao, W., Windley, B.F., Cai, F., Sein, K., Naing, S., 2017a. Early Cretaceous wedge extrusion in the Indo-Burma Range accretionary complex: implications for the Mesozoic subduction of Neothethys in SE Asia. International Journal of Earth Sciences 106, 1391-1408. 
Zhang, J., Xiao, W.J., Windley, B.F., Wakabayashi, J., Cai, F.L., Sein, K., Wu, H., Naing, S., 2018. SE Asia. Earth-Science Reviews 185, 704-731.

755 Zhang, P., Mei, L.F., Hu, X.L., Li, R.Y., Wu, L.L., Zhou, Z.C., Qiu, H.N., 2017b. Structures, uplift, and magmatism of the Western Myanmar Arc: Constraints to mid-Cretaceous-Paleogene tectonic evolution of the western Myanmar continental margin. Gondwana Research 52, 18-+. Zhang, P., Najman, Y., Mei, L., Millar, I., Sobel, E., Carter, A., Barfod, D., Dhuime, B., Garzanti, E., Govin, G., Vezzoli, G., Hu, X., 2019. Palaeodrainage evolution of the large rivers of East Asia and Himalayan-Tibet tectonics. Earth Science Reviews In press. 


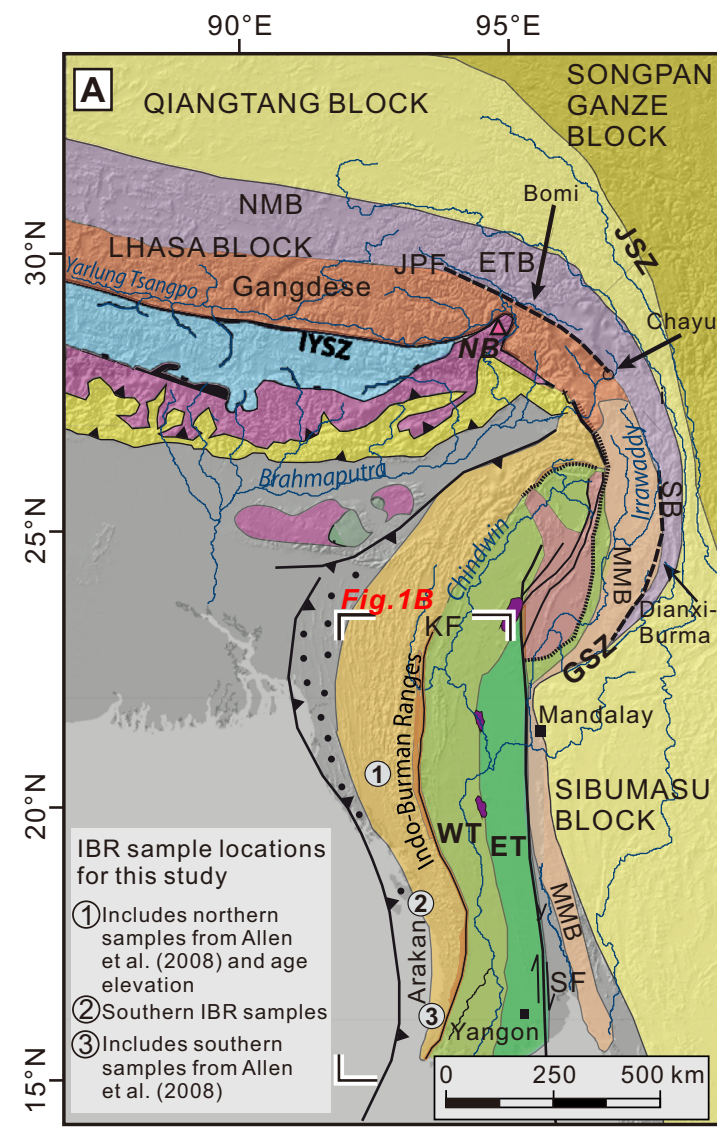

Tibet, India and China

$\square$ Lesser Himalayan Series
Greater Himalayan Series
Tethyan Himalayan Series
Southern Lhasa block with Gangdese
batholith \& Nyingchi Metamorphic Complex
Northern Lhasa block with
Northern Magmatic Belt (NMB) \&
Eastern Transhimalayan batholiths (ETB)
Qiangtang block
Songpan-Ganze block
Suture zones
IYSZ-Indus-Yarlung Tsangpo Suture Zone
JSZ-Jinsha Suture Zone
-- JPF: Jiali-Parlung Fault
NB: Namche Barwa, Eastern Syntaxis

\section{Myanmar}

Upper Oligocene-Pliocene rocks of the Eastern Trough (ET), Central Myanmar Basin Albian-Pliocene rocks of the Western Trough (WT), Central Myanmar Basin

.. Neogene ssts and msts of the Indo-Burman Ranges and equivalent in Bangladesh

Late Cretaceous and Palaeogene ssts and msts of the Indo-Burman Ranges

$\square$ Upper Triassic ssts, Jurassic ophiolites \& cherts over Kanpetlet metamorphic rocks and msts of the Indo-Burman Ranges

Precambrian rocks, Jurassic ophiolites, lowgrade metamorphic rocks \& Cenozoic volcanic and sedimentary rocks in the northern Myanmar

Mogok Metamorphic Belt (MMB)

Slate Belt (SB)

Shan-Thai Block SF-Sagaing Fault Kabaw Fault

Wuntho-Popa Arc

Gaoligong Shear Zone

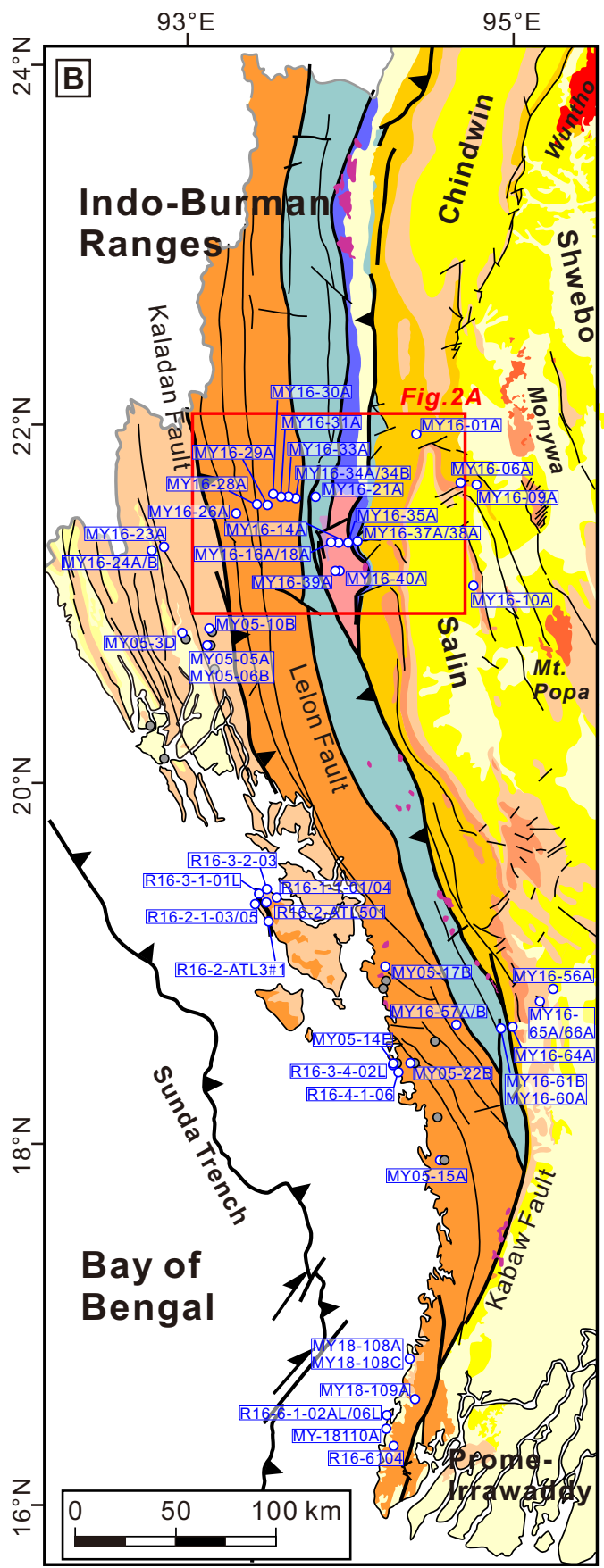

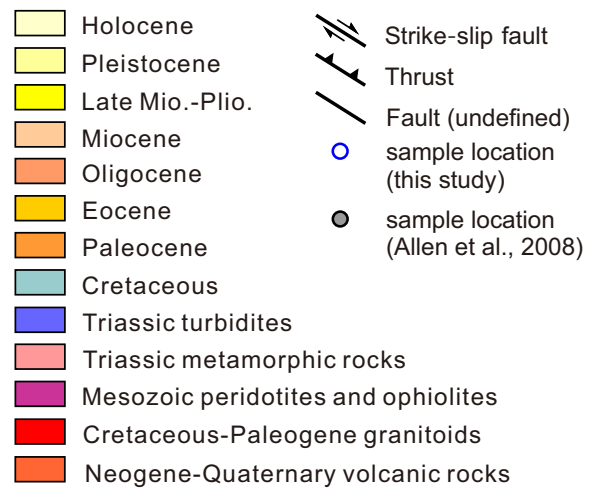




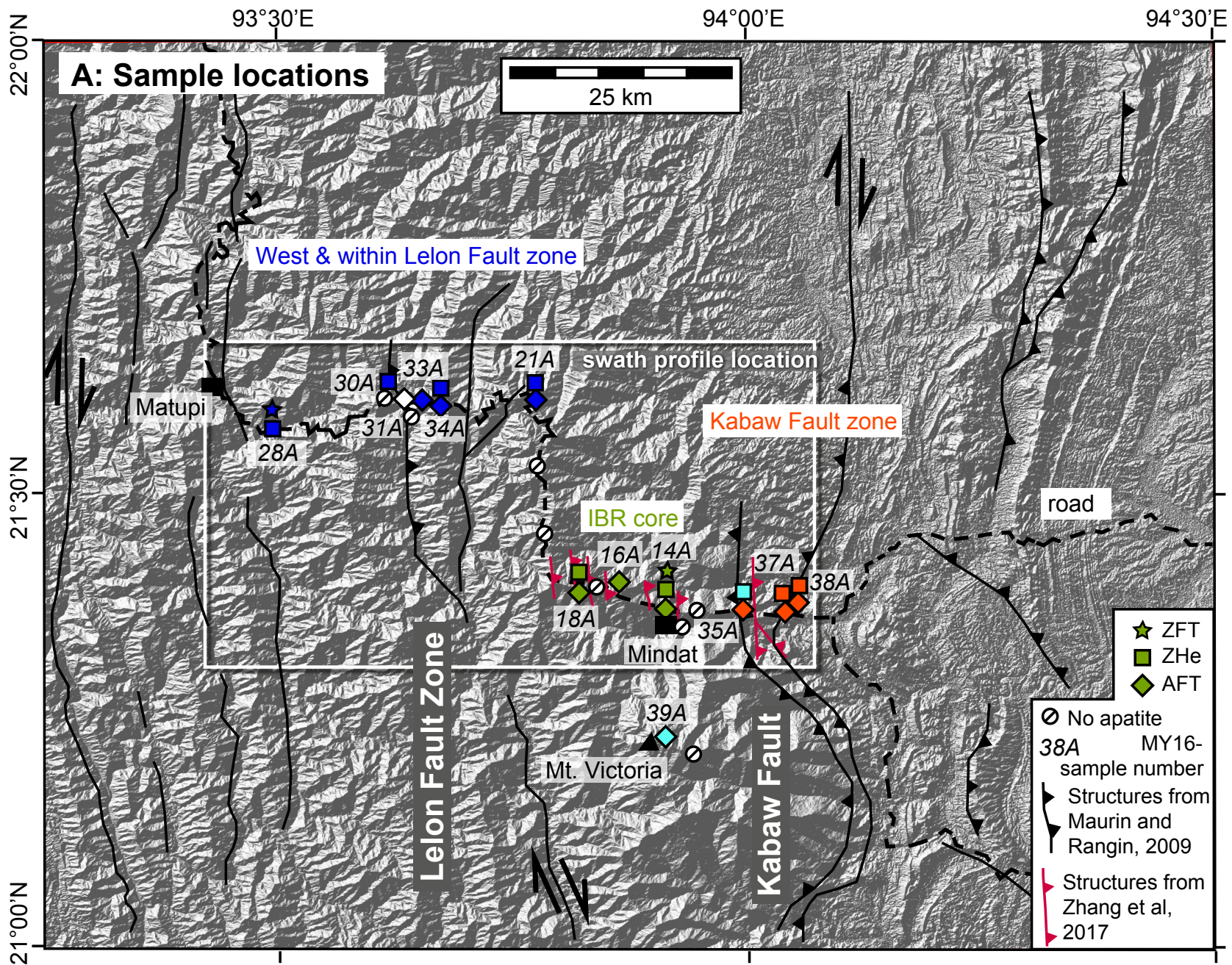

\section{B: Swath profile}

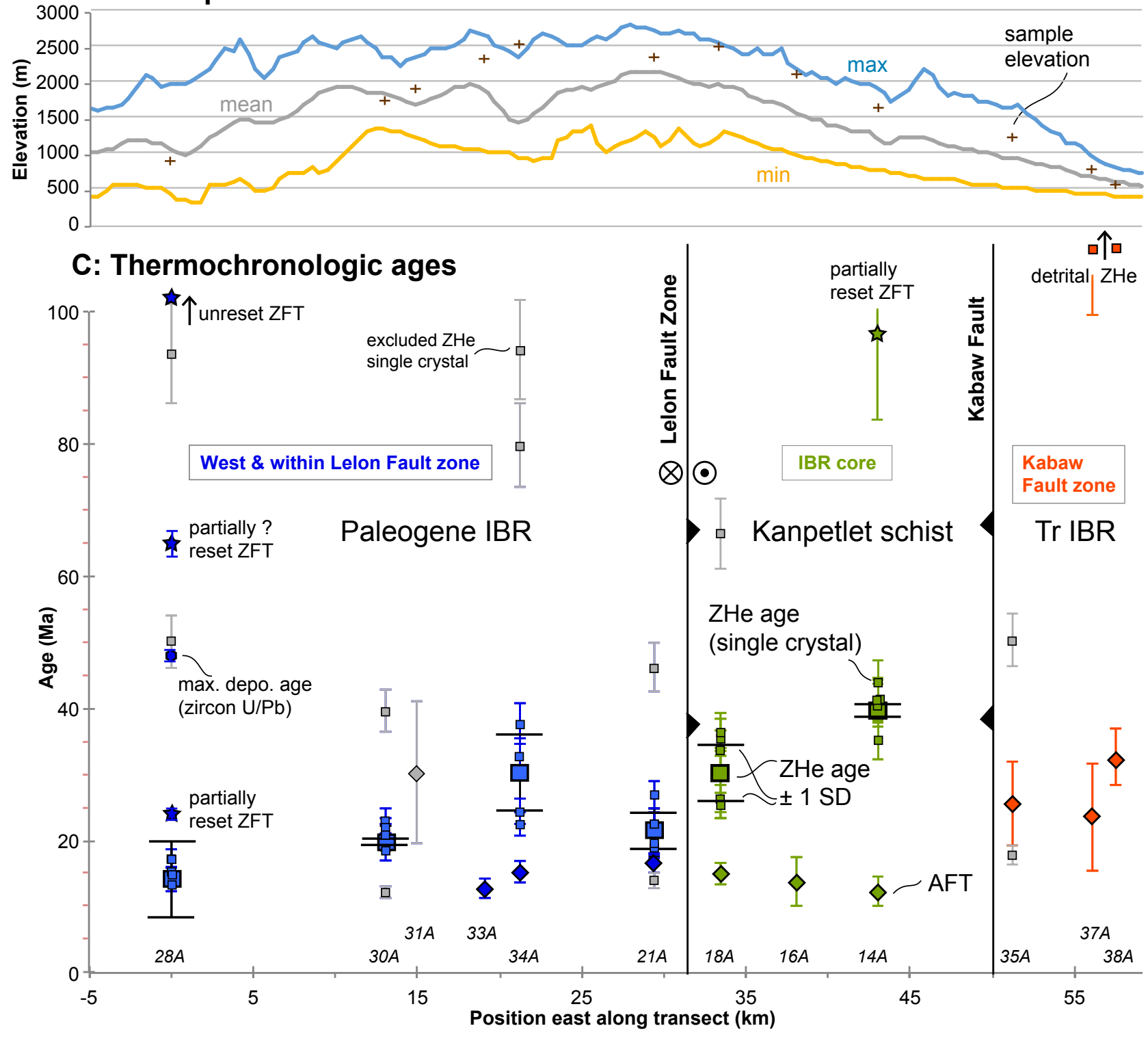




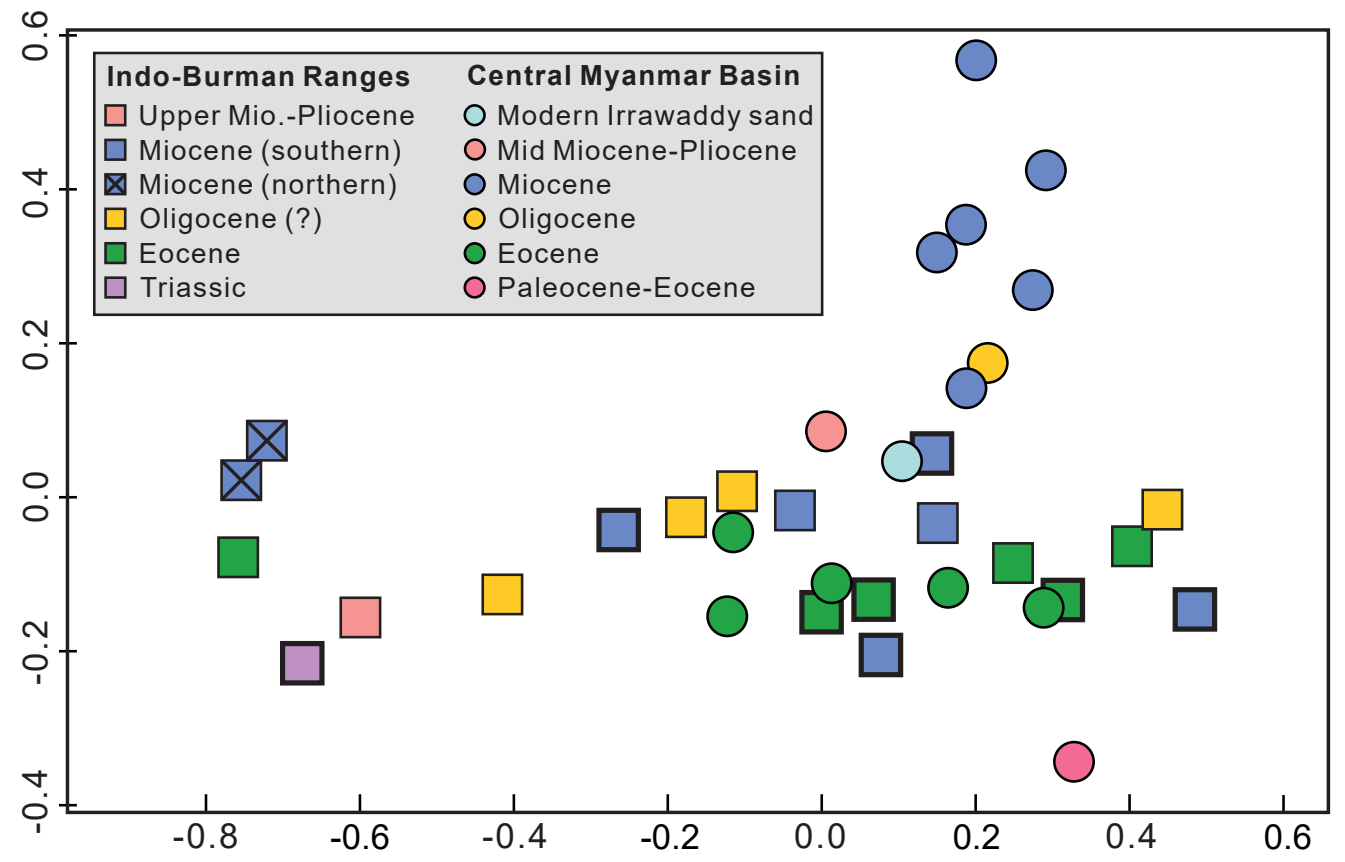



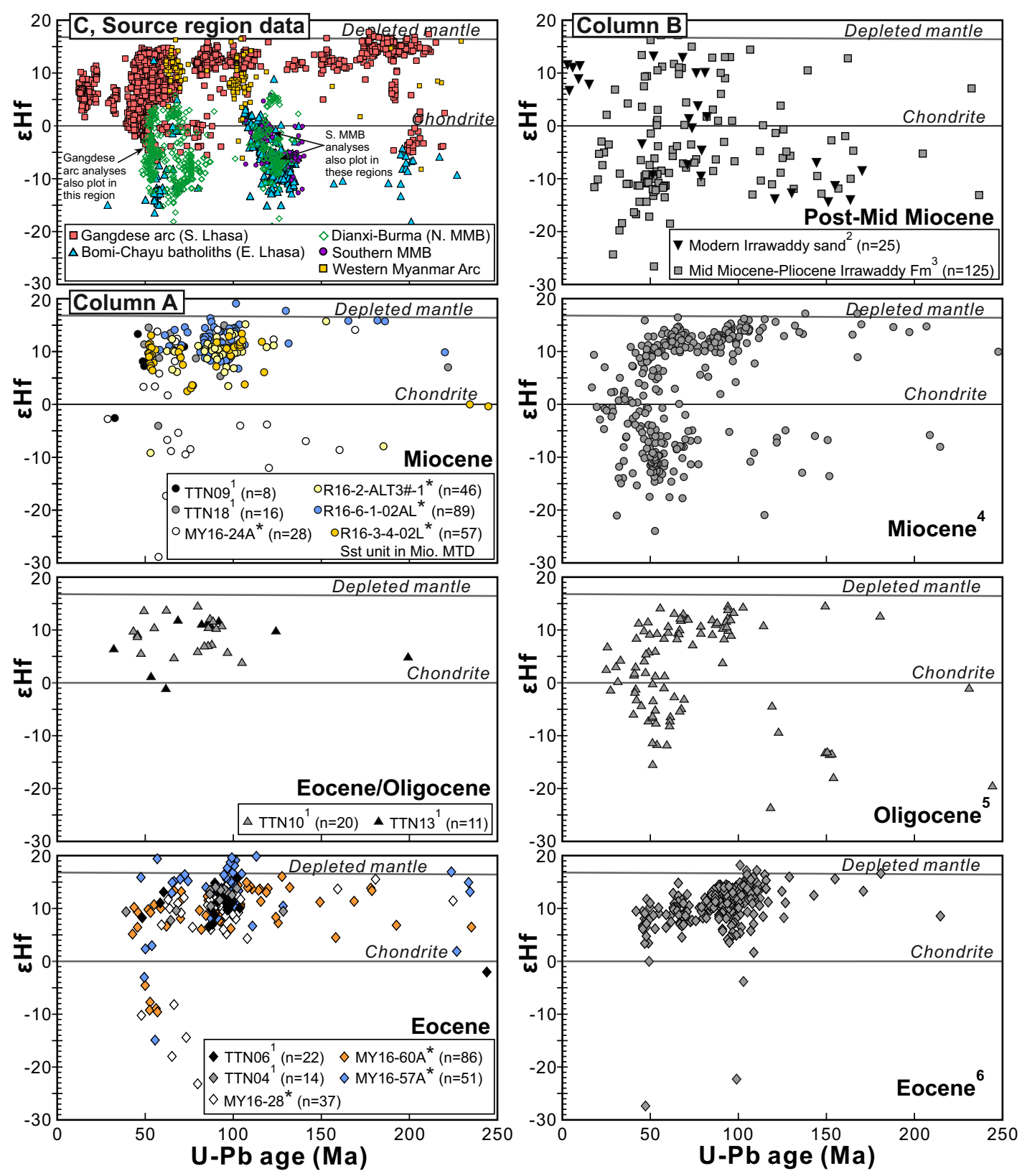

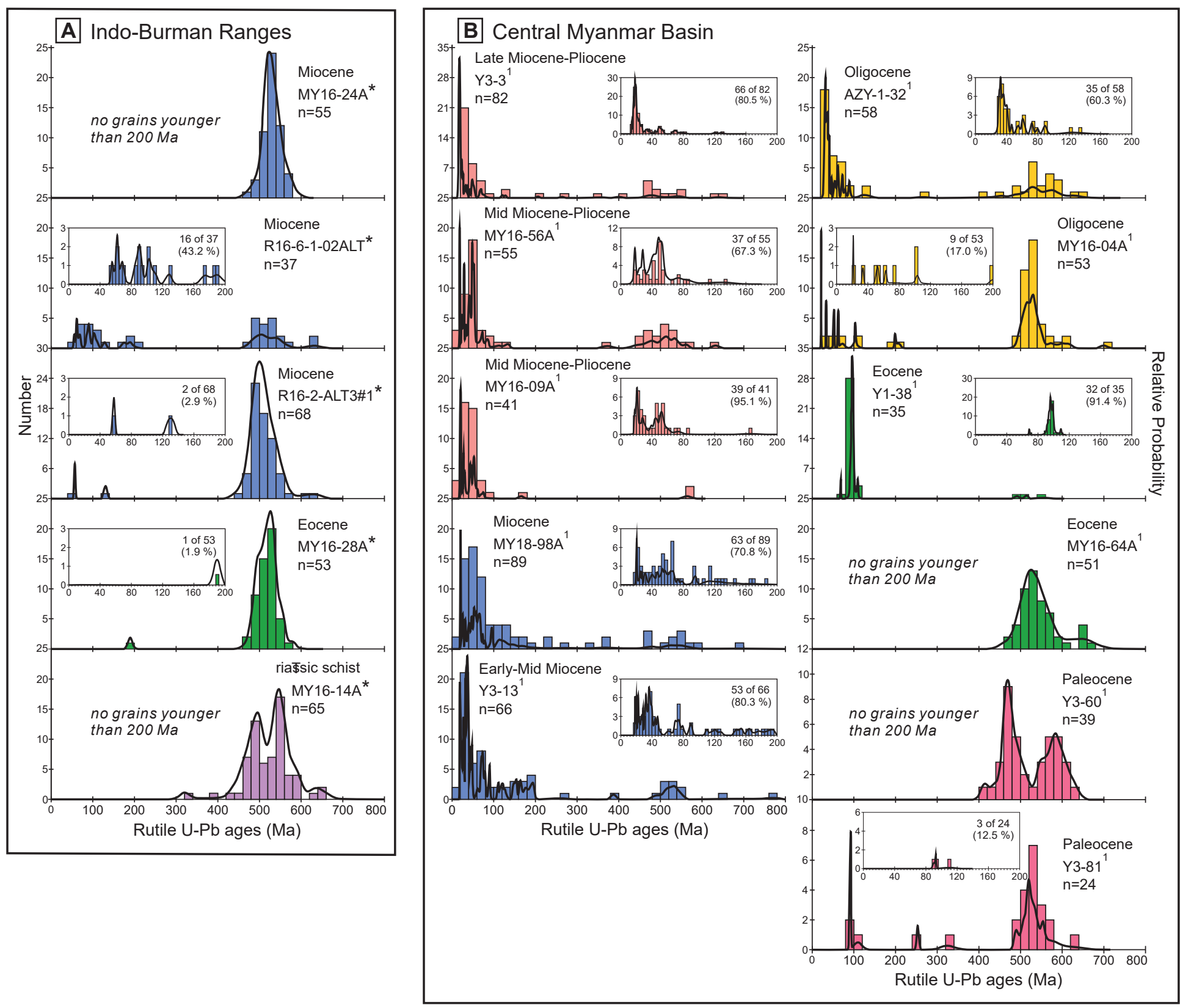


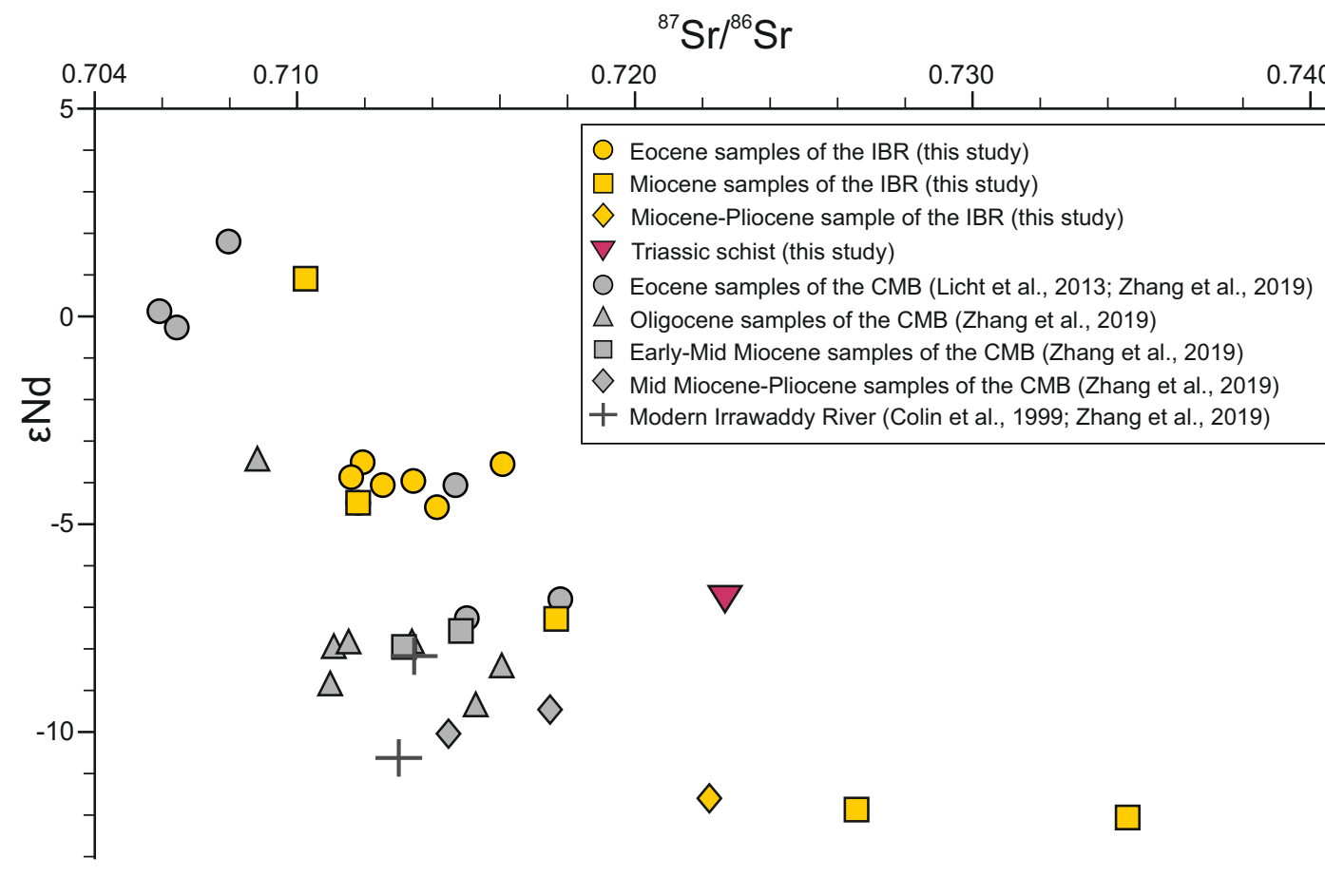




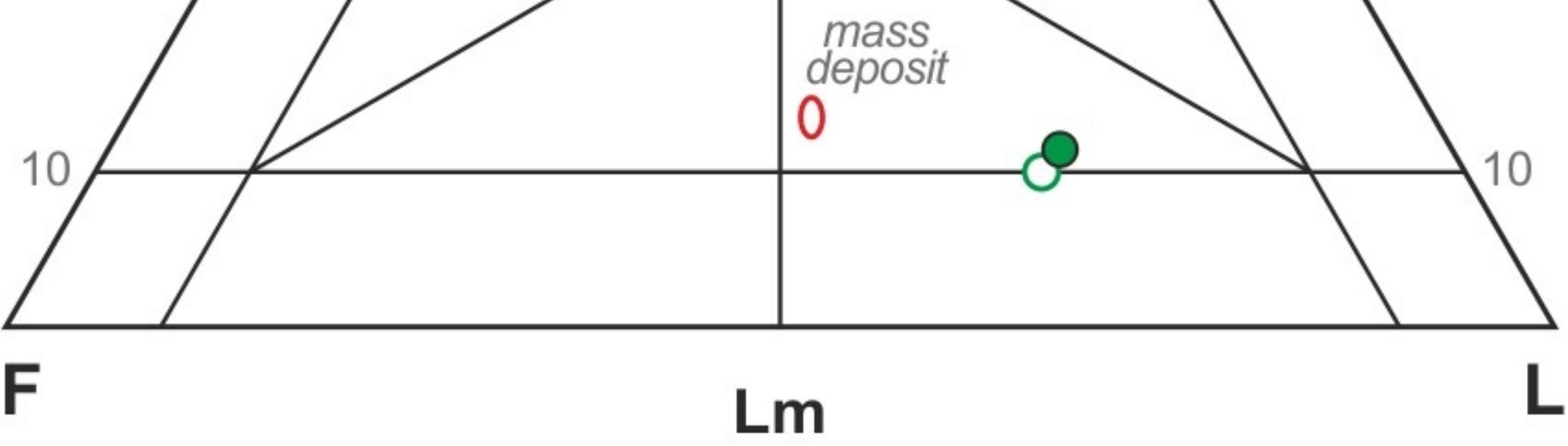

INDO-BURMAN RANGES

Miocene

O Eocene

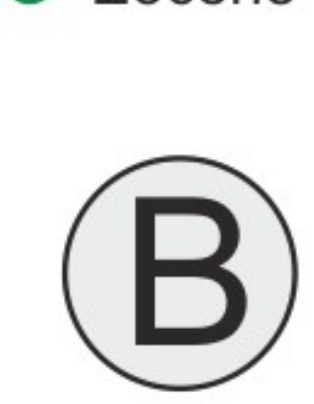

/Pliocene

CENTRAL MYANMAR BASIN

$\bigcirc$ upp.Mioc./Pliocene - Miocene - Oligocene

○oc./Olig. boundary Eocene 

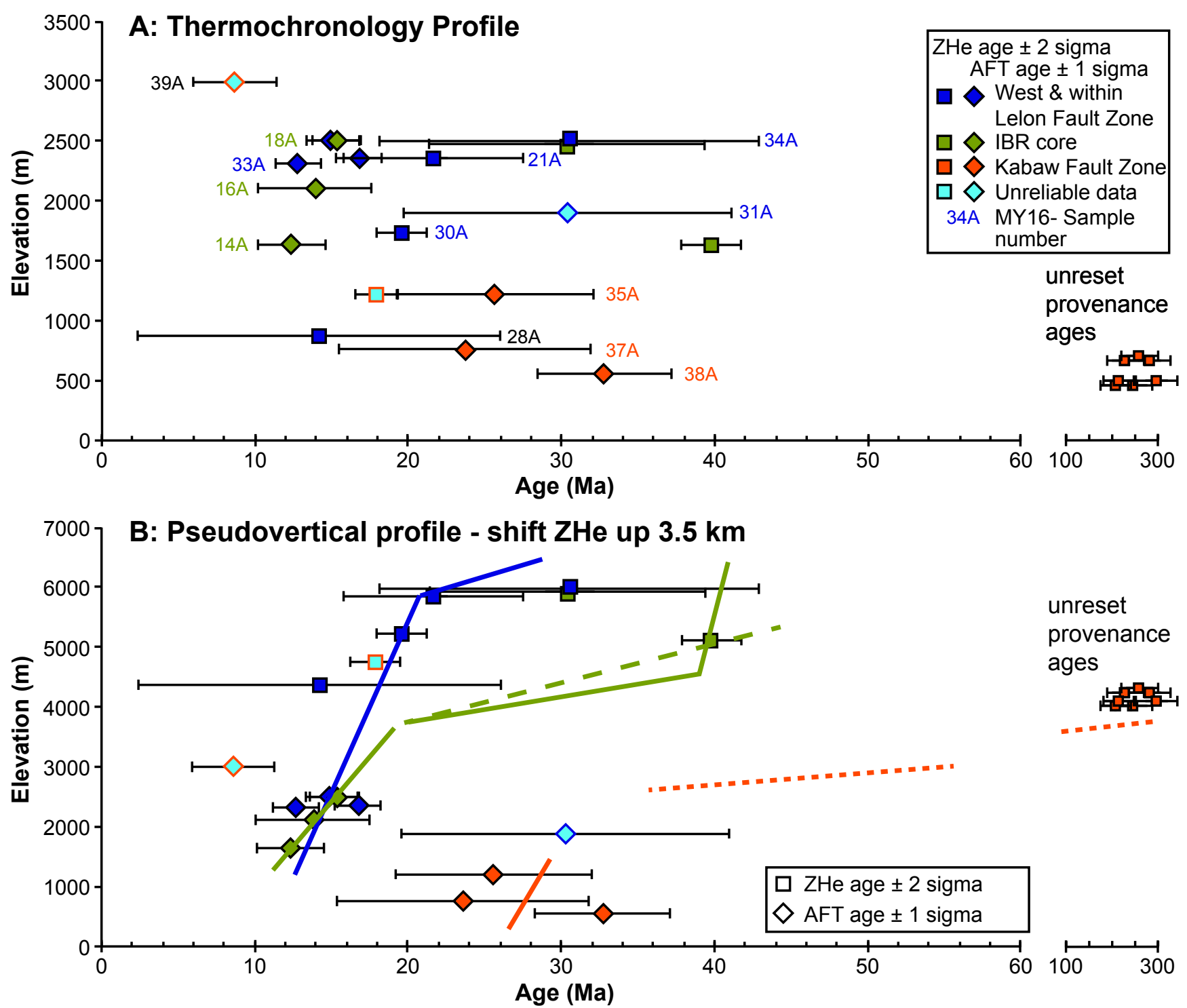